\title{
Evaluation of prevalence, biochemical profile, and drugs associated with chronic kidney disease-mineral and bone disorder in $\mathbf{1 1}$ dialysis centers
}

Avaliação da prevalência, perfil bioquímico e drogas associadas ao distúrbio mineral ósseo-doença renal crônica em 11 centros de diálise

\section{Authors}

Rodrigo Reis Abrita ${ }^{1}$

Beatriz dos Santos Pereira ${ }^{2}$

Neimar da Silva Fernandes ${ }^{1}$

Renata Abrita ${ }^{1}$

Rosalia Maria Nunes Henriques Huaira $^{1}$

Marcus Gomes Bastos ${ }^{1}$

Natália Maria da Silva Fernandes

1 Universidade Federal de Juiz de Fora, Juiz de Fora, MG, Brasil. ${ }^{2}$ Centro de Ensino Superior de Juiz de Fora, Passos, Juiz de Fora, MG, Brasil.
Submitted on: 06/03/2016. Approved on: 10/19/2017.

\section{Correspondence to:}

Natália Fernandes.

E-mail: nataliafernandes02@ gmail.com

\section{Abstract}

Introduction: The diagnosis and treatment of mineral and bone disorder of chronic kidney disease (CKD-MBD) is a challenge for nephrologists and health managers. The aim of this study was to evaluate the prevalence, biochemical profile, and drugs associated with CKD-MBD. Methods: Cross-sectional study between July and November 2013, with 1134 patients on dialysis. Sociodemographic, clinical, and laboratory data were compared between groups based on levels of intact parathyroid hormone (iPTH) $(<150,150-300$, 301-600, 601-1000, and > $1001 \mathrm{pg} / \mathrm{mL}$ ). Results: The mean age was $57.3 \pm 14.4$ years. The prevalence of iPTH $<150 \mathrm{pg} /$ $\mathrm{mL}$ was $23.4 \%$ and $\mathrm{iPTH}>601 \mathrm{pg} / \mathrm{mL}$ was $27.1 \%$. The comparison between the groups showed that the level of iPTH decreased with increasing age. Diabetic patients had a higher prevalence of iPTH < $150 \mathrm{pg} / \mathrm{mL}$ (27.6\%). Hyperphosphatemia (> $5.5 \mathrm{mg} / \mathrm{dL}$ ) was observed in $35.8 \%$. Calcium carbonate was used by $50.5 \%$, sevelamer by $14.7 \%, 40 \%$ of patients had used some form of vitamin D and 3.5\% used cinacalcet. Linear regression analysis showed a significant negative association between iPTH, age, and diabetes mellitus and a significant positive association between $\mathrm{PTH}$ and dialysis time. Conclusion: The prevalence of patients outside the target for iPTH was $50.5 \%$. There was a high prevalence of hyperphosphatemia $(35.8 \%)$, and the minority of patients were using active vitamin $\mathrm{D}$, vitamin $\mathrm{D}$ analogs, selective vitamin $\mathrm{D}$ receptor activators, and cinacalcet. These data indicate the need for better compliance with clinical guidelines and public policies on the supply of drugs associated with CKD-MBD.

Keywords: Chronic renal failure; renal dialysis; bone diseases.

\section{Resumo}

Introdução: $\mathrm{O}$ diagnóstico e tratamento do distúrbio mineral ósseo-doença renal crônica (DMO-DRC) é um desafio para os nefrologistas e gestores de saúde. O objetivo deste estudo foi avaliar a prevalência, perfil bioquímico, e drogas associadas a DMODRC. Métodos: Estudo transversal entre julho e novembro de 2013, em 11 centros com 1134 pacientes em diálise. Dados sociodemográficos, clínicos, e laboratoriais foram comparados entre os grupos, com base em níveis do paratormônio intacto (PTHi) $(<$ 150,151-300, 301-600,601-1000, e > 1001 $\mathrm{pg} / \mathrm{mL}$ ). Resultados: A idade média foi de $57,3 \pm 14,4$ anos, 1071 pacientes estavam em hemodiálise, e 63 em diálise peritoneal. A prevalência de PTHi $<150 \mathrm{pg} / \mathrm{mL}$ foi $23,4 \%$ e PTHi > $601 \mathrm{pg} / \mathrm{mL}$ foi de $27,1 \%$. A comparação dos grupos mostrou que o nível de PTHi diminuiu com o aumento da idade. Pacientes diabéticos apresentaram uma maior prevalência de PTHi $<150$ pg/ $\mathrm{mL}(27,6 \%)$. Carbonato de cálcio foi usado por $50,5 \%$, Sevelamer por $14,7 \%, 40 \%$ dos pacientes utilizaram alguma forma de vitamina $D$, e 3,5\% utilizaram cinacalcet. A hiperfosfatemia (> 5,5mg/dL) foi observada em $35,8 \%$. A análise de regressão linear mostrou uma associação negativa significativa entre PTHi, idade, e diabetes mellitus e uma associação positiva significativa com o tempo em diálise. Conclusão: A prevalência de pacientes fora do alvo para PTHi foi de $50,5 \%$. Houve uma alta prevalência de hiperfosfatemia e um baixo uso de vitamina $\mathrm{D}$ ativa, análogos da vitamina $\mathrm{D}$, ativadores seletivos da vitamina $\mathrm{D}$, e cinacalcet. Estes dados chamam a atenção para a necessidade de uma maior conformidade com as diretrizes e políticas públicas sobre o fornecimento de medicamentos associados à DMO-DRC.

Palavras-chave: Falência renal crônica; diálise renal; doenças ósseas. 


\section{INTRODUCTION}

Brazil is the largest country in Latin America, and the only country over 100 million people with a public health system (SUS) that assures universal access to health care since 1990. According to the Brazilian Institute of Geography and Statistics (IBGE), in 2015 Brazil had a population of $203,980,840$ million people, with a human development index of 0.749 and life expectancy of 74.9 years ${ }^{1}$. The country is undergoing a demographic change characterized by population ageing, with the elderly comprising 31 million people. The prevalence of arterial hypertension among the population over 40 years old is $40 \%-50 \%{ }^{2}$. According to the International Diabetes Federation, there are nearly 11.6 million diabetic individuals in Brazil ${ }^{3}$. Since the Brazilian Dialysis Survey was created by the Brazilian Society of Nephrology, the number of people on dialysis in the country has increased progressively, and was estimated to be 100,397 in the 2013 survey $^{4}$.

One of the comorbidities associated with CKD is the mineral and bone disorder (CKD-MBD), a syndrome which encompasses clinical, biochemical (calcium, phosphate, parathyroid hormone, and active vitamin D), and bone abnormalities (bone remodeling, mineralization, and bone volume), in addition to the comorbidities associated with extra-skeletal calcification and cardiovascular disturbances ${ }^{5}$. The broadly used term 'renal osteodystrophy' is currently used to define changes in bone histology evaluated by biop$\mathrm{sy}^{5}$. Based on bone remodeling, renal osteodystrophy is classified as either a high remodeling bone disease (secondary hyperparathyroidism or osteitis fibrosa) or a low remodeling bone disease (represented by osteomalacia and adynamic bone disease). In addition, a mixed bone disease can occur, which presents both high and low remodeling characteristics and is currently classified as high remodeling ${ }^{5}$.

Most evidence shows that adynamic bone disease characterized by low bone turnover occurs in the early stages of chronic kidney disease in a significant proportion of patients. This could be due to the initial predominance of bone turnover inhibitory conditions such as resistance to parathyroid hormone $(\mathrm{PTH})$, reduced calcitriol levels, sex hormone deficiency, diabetes mellitus, and uremic toxins leading to suppression of various means of bone signaling. In later stages, osteitis fibrosa, a high-turnover bone disease, develops resulting mainly from secondary hyperparathyroidism ${ }^{6}$.
In 1998, Diaz Lopez et al. evaluated the epidemiology of renal osteodystrophy in 1209 bone biopsies from patients in five Ibero-American countries (Brazil, Uruguay, Argentina, Portugal, and Spain) and showed that hyperparathyroidism was more frequent in patients on dialysis in Spain and Portugal (66 and 70\%, respectively), whereas mixed and low-bone remodeling lesions accounted for less than $14 \%$. On the other hand, South American patients showed a high prevalence of mixed and low-bone remodeling lesions (37 and $51 \%$, respectively) ${ }^{7}$. The study by Araújo SM et al. evaluated the prevalence of CKD-MBD in dialysis patients in Brazil and Uruguay and showed, through bone biopsy, an increase of prevalence of secondary hyperparathyroidism from $32.3 \%$ in $1985-1990$ to $44 \%$ in $1997-2000$ in 2,340 Brazilian patients ${ }^{8}$. According to data from the 2011 Brazilian Census of Parathyroidectomy, the prevalence of severe secondary hyperparathyroidism was $10.7 \%$, based on levels of intact parathyroid hormone (iPTH) higher than $1000 \mathrm{pg} / \mathrm{mL}$, indicative of parathyroidectomy ${ }^{9}$.

A study published in 2011 and conducted in hemodialysis centers in Argentina, Chile, Colombia, Venezuela, Mexico, and Brazil (CORES Study) involving 16,173 patients analyzed the impact of calcium, phosphate, and iPTH levels in mortality and concluded that low or high serum levels of all variables raised the risk of death ${ }^{10}$. Abnormalities in serum phosphorus, calcium, and parathyroid hormone have been associated with poor survival in dialysis patients. A total of 4,500 patients were randomly recruited for COSMOS study from 227 dialysis centers in 20 European countries. In summary, a non-linear relationship was found between serum CKD-MBD biochemical parameters and mortality risk. Low and high serum levels of serum phosphorus, calcium, and PTH were associated with a higher relative risk of mortality while decreases in serum phosphorus and calcium and increases in serum PTH during followup were associated with a significant lower risk of mortality ${ }^{11}$.

iPTH levels below $150 \mathrm{pg} / \mathrm{mL}$ were seen in $36 \%$ of 3,226 incident and prevalent patients treated with peritoneal dialysis in Brazil (continuous ambulatory peritoneal dialysis or automated peritoneal dialysis ${ }^{12}$.

Historically, renal osteitis fibrosa and mixed uremic osteodystrophy were the most prevalent bone diseases in patients with CKD. Recently, an increase in the prevalence of adynamic bone disease has been observed, particularly in diabetic patients ${ }^{6,13}$. 
Although abundant, the studies cited above show partial data or were based on patients followed in a reference center for CKD-MBD, thus are subject to bias. The evaluation of CKD-MBD patterns, practices, and epidemiology is fundamental for public health programs. In Brazil, there are considerable difficulties in keeping records on specific pathologies and, especially, planning strategies based on accurate information. Thus, studies assessing occurrences in the various regions of the country, characterized by different realities, are vital for better healthcare planning. Since there is a lack of an extensive evaluation of patients on hemodialysis (HD) and peritoneal dialysis PD in Brazil, the aim of this study was to evaluate the prevalence, biochemical profile, and drugs associated with CKD-MBD in these patients.

\section{Material AND Methods}

\section{STUDY DESIGN AND SETTING}

We performed a cross-sectional study in 11 nephrology centers run by the Nephrology Centers Association of the State of Minas Gerais (Associação Mineira de Centros de Nefrologia - AMICEN), which covers 2,371,572 people $^{14}$. The association includes 19 renal replacement therapy (RRT) centers, distributed across the East, South, Northeast, Midwest and central areas of Minas Gerais, Brazil.

The present study was performed according to the Declaration of Helsinki and approved by the Ethics and Research Committee of the Hospital of the Federal University of Juiz de Fora, Brazil (Universidade Federal de Juiz de Fora), under the following number: 21702913.9.0000.5147.

\section{StUdy POPULATION}

The inclusion criteria were patients with CKD over 18 years old on dialysis (HD or PD) for more than 3 months, with at least one iPTH dosage in 2013 and who have signed the informed consent form. The exclusion criteria were patients less than 18 years old and who were missing laboratorial iPTH dosage within the period of study.

\section{STUdY PROCEDURES AND MEASUREMENTS}

Data were based on medical records and on the laboratorial evaluation obtained in July and November 2013. For this purpose, the NEFRODATA ${ }^{\circledR}$ software (medical registry) was used. The following socio-demographic variables were analyzed: age, sex, race, income, and level of education (according to the IBGE). The following clinical variables were analyzed: CKD etiology, associated comorbidities, and dialysate calcium concentration. Laboratorial variables included hemoglobin (g/dL), urea (UV enzymatic method $-\mathrm{mg} / \mathrm{dL}$ ), creatinine (kinetic Jaffe method - $\mathrm{mg} / \mathrm{dL}$ ), albumin (bromocresol green colorimetric method - g/dL), iron (ferrozine colorimetric method - $\mu \mathrm{g} / \mathrm{dL}$ ), total serum calcium (Arsenazo III method - mg/dL), serum phosphate (phosphomolybdate UV method - mg/dL), alkaline phosphatase (colorimetric method - modified from Bowers and McComb - U/L), iPTH (chemiluminescence method - pg/mL) and aluminum (atomic absorption spectroscopy method with Zeeman correction - $\mu \mathrm{g} / \mathrm{L}$ ).

The following drugs used in CKD-MBD therapy were also evaluated: phosphate binders (calcium carbonate, calcium acetate, and sevelamer), active vitamin D (calcitriol oral and venous), vitamin D analogues (alfacalcidol), selective vitamin $\mathrm{D}$ receptor activators (paricalcitol), and calcimimetics (cinacalcet). The number of parathyroidectomies conducted in 2013 was also recorded.

\section{STATISTICAL ANALYSIS}

A descriptive analysis was initially carried out and the data were reported by the mean \pm standard deviation, median (interquartile range) or percentage, depending on the variable. The population was divided based on iPTH levels $(<1$ 50; 151-300; 301-600; $601-1000>1000 \mathrm{pg} / \mathrm{mL}$ ) according to Douthat et al. who published a study based on 25 dialysis centers in Argentina ${ }^{15}$. The socio-demographic, clinical, and laboratorial data were compared between groups through ANOVA, chi-square or Mann-Whitney tests. The comparison between dialysis modality vs laboratorial variables and diabetes mellitus (yes and no) vs laboratorial variables by Student's t-test or chi-square. Linear regression analysis was used to determine which variables influenced iPTH levels. Pearson's or Spearman's correlations were performed between the levels of iPTH and clinical and laboratory variables. The criteria for inclusion in multivariate regression was statistical and/or clinical significance. iPTH dosage was used as the dependent variable and the following predictor variables were used in model 1: age, diabetes mellitus, duration of therapy, and therapy modality. A confidence interval of $95 \%$ with $p<0.05$ was used and the software was IBM's SSPS 15.0 . 


\section{REsults}

Of the 19 AMICEN dialysis centers invited to participate in the study, 11 provided data on their patients. Although 1219 patients were initially considered eligible, 85 were later excluded from the study for one of the following reasons: less than 18 years old, on dialysis for less than 3 months or missing laboratorial iPTH dosage within the study period. Out of the 1134 patients evaluated, the mean age was $57.3 \pm 14.4$ years, varying from $19-96,55.6 \%$ were males, $67 \%$ had elementary school education, and the monthly median income was US\$274. The socio-demographic characteristics of the patients according to iPTH levels are summarized in Table 1.

The main etiology of CKD was hypertensive nephropathy $(40.9 \%)$, followed by diabetic renal disease $(24.3 \%)$. The majority of the patients presented with hypertension $(80.4 \%), 32.9 \%$ were diabetic, and $11.8 \%$ had cardiovascular disease. Regarding dialysis treatment, 1071 patients were on HD (94.4\%) and 63 were on PD $(5.6 \%)$. The median duration of dialysis was 43 months (21-88), varying from 4 and 274 months of therapy (Table 1). PD patients were analyzed separately and no difference was found compared to the analysis in association with HD patients.

By comparing the different iPTH groups, it was observed that iPTH level decreases with increasing age $(60.4 \pm 14.9$ vs. $51.4 \pm 13.2, p<0.0001)$. Patients who had diabetic kidney disease had a higher prevalence of iPTH lower than $150 \mathrm{pg} / \mathrm{mL}(27.6 \%)$ and a lower prevalence of iPTH greater than $1000 \mathrm{pg} / \mathrm{mL}$ $(2.4 \%)$. Patients with diabetes mellitus, either as the cause of CKD or as comorbidity, had a higher prevalence of iPTH $<150 \mathrm{pg} / \mathrm{mL}(27.8 \%)$ and lower prevalence of iPTH $>1000 \mathrm{pg} / \mathrm{mL}(4.7 \%)$.

A higher percentage of patients with $\mathrm{iPTH}<150$ $\mathrm{pg} / \mathrm{mL}$ was found in PD compared with HD $(33.3 \%$ vs. $22.8 \%$ with $p=0.19$ ); however, the difference was statistically significant, probably due to the low number of patients on PD. A longer duration of therapy was associated with a higher iPTH serum level (53.7 vs. 85.9 months with $p<0.001$, Table 1 ).

The majority of the patients used calcium carbonate as a phosphate binder $(50.5 \%)$, and $14.7 \%$ used non-calcium-based binders (Sevelamer). Over $40 \%$ of the patients used active vitamin D (Calcitriol), vitamin $\mathrm{D}$ analogues (Alfacalcidol) or selective vitamin D receptor activators (Paricalcitol) (Table 2).
Table 2 also shows that $44.3 \%$ of the patients with $\mathrm{iPTH}<150 \mathrm{pg} / \mathrm{mL}$ were using calcium-based phosphate binders, of whom $14 \%$ used non-calciumbased binders. In relation to vitamin $\mathrm{D}$, the largest percentage of patients with iPTH $>600 \mathrm{pg} / \mathrm{mL}$ used intravenous calcitriol $(55.7 \%)$. Patients with iPTH $<150 \mathrm{pg} / \mathrm{mL}$ used some form of vitamin D $(30.7 \%)$. Calcimimetics were used by $3.5 \%$ of the patients and $72.5 \%$ had iPTH $>600 \mathrm{pg} / \mathrm{mL}$.

Table 3 shows the laboratorial variables for the different iPTH levels. Urea and serum creatinine levels were lower in patients with iPTH $<150 \mathrm{pg} / \mathrm{mL}(\mathrm{p}<0.001)$, without differences in $\mathrm{Kt} / \mathrm{V}(p=0.34)$ or in serum albu$\min (p=0.74)$. The levels of serum calcium, phosphate, and alkaline phosphatase increased with the increasing serum level of iPTH ( $p<0.001$ for all variables).

The median $\mathrm{iPTH}$ in the studied population was $327.7 \mathrm{pg} / \mathrm{mL}$ (P25:161.2 pg/mL - P75: $647 \mathrm{pg} / \mathrm{mL}$ ), varying from $1.3-3264 \mathrm{pg} / \mathrm{mL}$. The prevalence of patients with iPTH $>600 \mathrm{pg} / \mathrm{mL}$ was $27.1 \%$ and with $\mathrm{PTH}<150 \mathrm{pg} / \mathrm{mL}$ was $23.4 \%$. Considering KDIGO targets for $\mathrm{iPTH}, 49.5 \%$ of the patients were in the $150-600 \mathrm{pg} / \mathrm{mL}$ range. Mean serum calcium was 9.3 $\pm 0.9 \mathrm{mg} / \mathrm{dL}$ and serum phosphate $5.1 \pm 1.6 \mathrm{mg} / \mathrm{dL}$. Hyperphosphatemia (phosphate concentration above $5.5 \mathrm{mg} / \mathrm{dL}$ ) occurred in $35.8 \%$ of the studied population and hypophosphatemia (phosphate concentration below $3.5 \mathrm{mg} / \mathrm{dL}$ ) in $13.5 \%$. Analysis of serum calcium showed that $39.3 \%$ of the patients had a concentration above $9.5 \mathrm{mg} / \mathrm{dL}$ (hypercalcemia) while in $12.6 \%$ it was lower than $8.4 \mathrm{mg} / \mathrm{dL}$ (hypocalcemia).

Concerning therapy modality, $11.6 \%$ of patients on HD and $15.9 \%$ on PD had a PTH above 1000 $\mathrm{pg} / \mathrm{mL}$, with $33.3 \%$ of the patients on PD presenting a iPTH $<150 \mathrm{pg} / \mathrm{mL}$ (Table 1). Hyperphosphatemia had a high prevalence both in patients on HD $(35.5 \%)$, and on PD (41.4\%).

A significant positive correlation was observed between calcium concentration in the dialysate and iPTH levels $(r=0.08 p=0.006)$, alkaline phosphatase $(\mathrm{r}=0.490 p<0.0001)$, and phosphorus $(\mathrm{r}=0.234 p$ $<0.0001)$.

Linear regression analysis demonstrated a significant negative association in model 1 between iPTH level and age and mellitus diabetes. The duration of therapy showed a significant positive association with the iPTH serum levels (Table 4). During 2013, there were no reports of parathyroidectomy in any of the patients of the study. 
TABLE 1 SOCIO-DEMOGRAPHIC AND CLINIC CHARACTERISTICS OF THE TOTAL POPULATION $(\mathrm{N}=1134)$ AND DIVIDED BY PTHI LEVEL GROUP

\begin{tabular}{|c|c|c|c|c|c|c|c|}
\hline \multirow[b]{2}{*}{ Variables } & \multirow{2}{*}{$\begin{array}{c}\text { Population } \\
n=1134\end{array}$} & \multicolumn{5}{|c|}{ PTHi (pg/mL) } & \multirow[b]{2}{*}{$p$} \\
\hline & & $\begin{array}{c}<150 \\
(n=265-23.4 \%)\end{array}$ & $\begin{array}{c}150-300 \\
(n=264-23.3 \%)\end{array}$ & $\begin{array}{c}300-600 \\
(n=298-26.2 \%)\end{array}$ & $\begin{array}{c}600-1000 \\
(n=173-15.3 \%)\end{array}$ & $\begin{array}{c}>1000 \\
(n=134-11.8 \%)\end{array}$ & \\
\hline $\begin{array}{l}\text { Age (years) } \\
\text { (Mean } \pm \text { standard } \\
\text { deviation) }\end{array}$ & $60.4 \pm 14.9^{a-b, c, d, e}$ & $58.3 \pm 14.3^{\mathrm{b}-\mathrm{a}, \mathrm{c}, \mathrm{d}, \mathrm{e}}$ & $57.6 \pm 14.1^{c-a, b, d, e}$ & $55.9 \pm 13.6^{d-a, b, c, e}$ & $\begin{array}{c}51.4 \pm \\
13.2^{e-a, b, c, d}\end{array}$ & $60.4 \pm 14.9^{a-b, c, d, e}$ & $<0.001$ \\
\hline \multicolumn{8}{|l|}{ Gender (\%) } \\
\hline \multicolumn{8}{|l|}{ Race (\%) } \\
\hline White & 48.9 & $23.4^{a-b, c, d, e}$ & $28.4^{b-a, c, d, e}$ & $25.0^{c-a, b, d, e}$ & $13.2^{d-a, b, c, e}$ & $10.0^{e-a, b, c, d}$ & \multirow{3}{*}{$<0.001$} \\
\hline Black & 24.9 & 18.9 & 15.7 & 28.5 & 19.9 & 17.1 & \\
\hline Brown & 26.2 & 27.8 & 20.7 & 26.4 & 14.9 & 10.2 & \\
\hline High School & 20.0 & 21.5 & 26.0 & 24.9 & 13.0 & 14.7 & \multirow{2}{*}{0.26} \\
\hline College & 4.9 & 30.2 & 18.6 & 25.6 & 11.0 & 14.0 & \\
\hline
\end{tabular}

\begin{tabular}{|c|c|c|c|c|c|c|c|}
\hline \multicolumn{8}{|l|}{ CKD etiology (\%) } \\
\hline Hyp. Nephropathy\# & 40.9 & $23.9^{a-b, d, e}$ & $20.8^{b-a, c, d, e}$ & $24.9^{c-s, d, e}$ & $18.6^{d-a, b, c, e e}$ & $11 \cdot 8^{e-a, b, c, d}$ & \multirow{4}{*}{$<0.001$} \\
\hline DRD\# & 24.3 & 27.6 & 26.4 & 32.9 & 10.6 & 2.4 & \\
\hline APKD\# & 3.5 & 25.7 & 22.9 & 31.4 & 8.6 & 11.4 & \\
\hline Unknown & 4.6 & 12.8 & 19.1 & 31.9 & 14.9 & 21.3 & \\
\hline $\begin{array}{l}\text { Arterial } \\
\text { Hypertension }\end{array}$ & 80.4 & 22.8 & 22.1 & $26.5^{c-d, e}$ & 15.3 & 13.3 & 0.01 \\
\hline Diabetes Mellitus & 32.9 & 27.8 & 26.4 & $29.5^{\mathrm{c}-\mathrm{d}, \mathrm{e}}$ & 11.6 & 4.7 & $<0.001$ \\
\hline$C V D^{*}$ & 11.8 & 23.1 & 22.2 & 29.9 & 15.4 & 9.4 & 0.84 \\
\hline Stroke & 3.7 & 24.3 & 21.6 & 32.4 & 13.5 & 8.1 & 0.88 \\
\hline Hepatic Cirrhosis & 0.3 & 0 & 66.7 & 0 & 0 & 33.3 & 0.17 \\
\hline Others & 34.3 & 23.0 & 26.8 & 25.9 & 14.5 & 9.8 & 0.50 \\
\hline \multicolumn{8}{|l|}{ Dialysis Modality (\%) } \\
\hline Hemodialysis & 94.4 & 22.8 & 23.7 & 26.4 & 15.5 & 11.6 & \multirow{2}{*}{0.17} \\
\hline Peritoneal Dialysis & 5.6 & 33.3 & 15.9 & 23.8 & 11.1 & 15.9 & \\
\hline
\end{tabular}

Therapy time

(months)

(Mean \pm standard

$61.9 \pm 54.0 \quad 53.7 \pm 52.0^{a-b, d, e}$

$55.2 \pm 48^{b-a, c, d, e}$

$53.5 \pm 49.5^{\mathrm{c}-\mathrm{b}, \mathrm{d}, \mathrm{e}}$

$<0.001$

deviation)

Dialysate Calcium

Concentration (\%)

\begin{tabular}{llllllll}
$3.5 \%$ & 16.7 & 35.1 & 23.9 & 17.6 & 13.8 & 9.6 & $<0.001$ \\
$3.0 \%$ & 37.4 & 27.0 & 22.0 & 22.9 & 16.1 & 12.1 \\
$2.5 \%$ & 45.8 & 16.0 & 24.3 & 31.9 & 15.3 & 12.5 \\
\hline
\end{tabular}

\# Hyp. Nephropathy- Hypertensive Nephrophaty; DKD: diabetic kidney disease; GN: glomerulonephritis; APKD: adult polycystic kidney disease; ${ }^{*}$ CVD: cardiovascular disease; PVD: peripheral vascular disease; COPD: chronic obstructive pulmonary disease; SLE: systemic lupus erythematosus. 


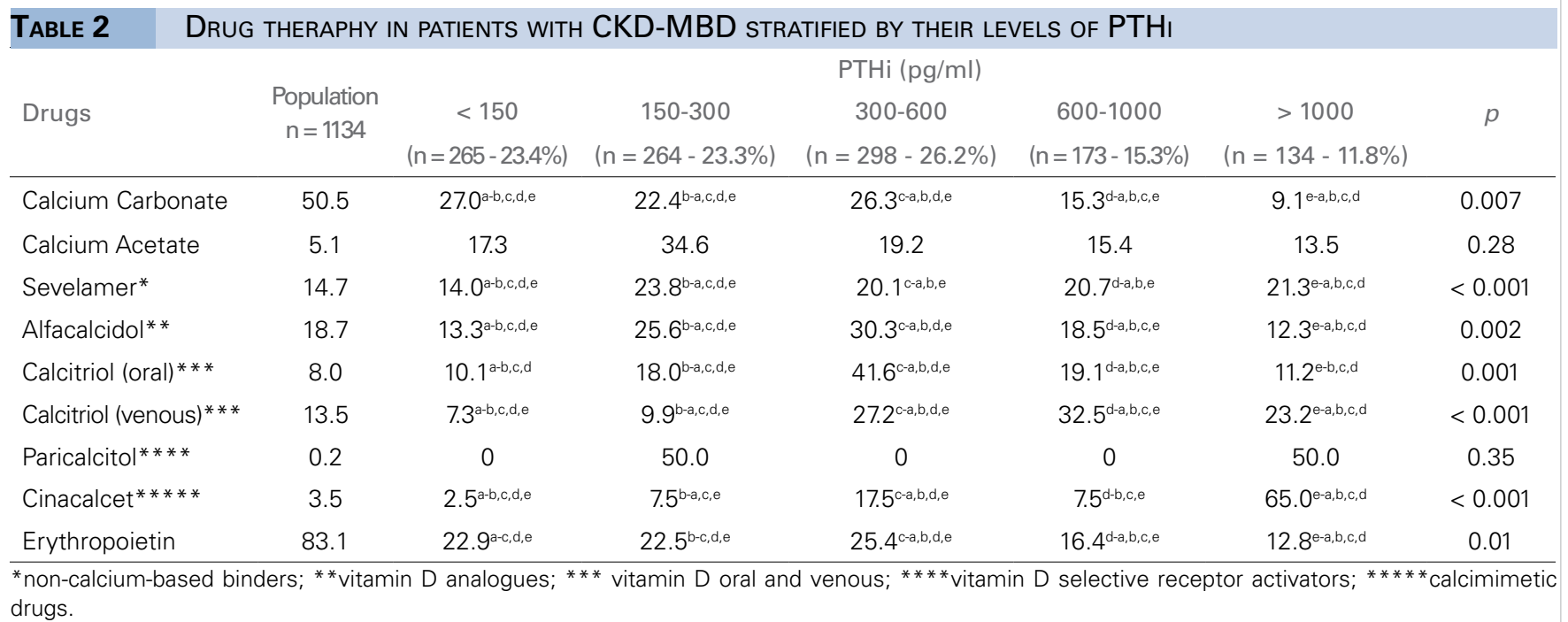

\section{Discussion}

In this study the prevalence of patients with $\mathrm{iPTH}<$ $150 \mathrm{pg} / \mathrm{mL}$ was $23.4 \%$ and with iPTH $>600 \mathrm{pg} / \mathrm{mL}$ was $27.1 \%$. The phosphate binders used by the majority of patients in relation to the iPTH level were calcium-based, most had vitamin D by oral route, and a small percentage used calcimimetics and selective vitamin D receptor activators.

Mean age and gender, and the main etiologies in our study are similar to those of the population on dialysis in Brazil ${ }^{4}$ and in Argentina, as shown in a study published in 2013, which reported on 1210 patients from 25 dialysis centers, with a mean age of $55.3 \pm$ 17.6 years and $60.8 \%$ of males ${ }^{15}$.

The sample used in this study represents around $1 \%$ of the Brazilian population on dialysis in $2013^{4}$. Regarding the modality of dialysis, our study had less patients on PD compared to the 2013 Brazilian Chronic Dialysis Survey $(5.6 \% \text { vs. 9.2\% })^{4}$.

A study conducted with 5008 patients on dialysis in Hungary demonstrated an inverse relationship between age and iPTH levels, regardless of diabetes mellitus ${ }^{16}$. Our results corroborate this conclusion, showing that age is inversely associated with $\mathrm{PPTH}$ level. This is probably due to a higher prevalence of low remodeling bone disorders ${ }^{13,17}$.

Race in the Brazilian population is a complex and controversial subject, since Brazil has the largest miscegenation in the world ${ }^{18}$. The lowest levels of iPTH in white and brown individuals and the highest levels in black individuals as observed in our study do not allow inferences about the general Brazilian population. As demonstrated by Dos Reis et al. in bone biopsies of individuals without $\mathrm{CKD}$, histomorphometric analysis results showed no association with gender and race in Brazil ${ }^{19}$. A study performed in the United States with 2056 patients reported that black patients in pre-dialytic and dialytic stages had lower serum levels of 25 hydroxyvitamin D and higher levels of iPTH when compared to white patients ${ }^{20}$. In a US study with 139,328 patients including 32\% AfricanAmericans on thrice weekly hemodialysis treatment in a single large dialysis organization, most laboratory values were measured monthly for up to 60 months (July 2001 to June 2006). The study found that African-Americans had higher serum calcium and PTH levels but similar concentrations of phosphorus and alkaline phosphatase and were more likely to receive injectable active vitamin $\mathrm{D}$ medications and at higher doses than their non-African-American counterparts ${ }^{21}$.

Diabetes Mellitus is known to be associated with low-remodeling bone disorder ${ }^{12,16,22}$. In our study, $39.3 \%$ of the patients with PTHi levels below $150 \mathrm{pg} /$ $\mathrm{mL}$ had diabetes mellitus, consistent with the recent review by Bover et al., in which low-remodeling bone disorder was associated, among other diseases, with diabetes mellitus ${ }^{13}$. Diabetes patients with CKD have lower rates of bone formation, a complication that often precedes CKD development. In these patients, there is a deficiency of vitamin D and an increase of advanced glycated end-products (AGE) as well as a decrease in osteoblast lifespan ${ }^{22}$. Concerning therapy modality, several authors have found lower levels of PTHi in PD than in $\mathrm{HD}^{23,24}$. However, no difference was observed in our study, probably due to the low number of patients on PD.

High-remodeling bone disorder develops early during CKD and continues evolving when patients 


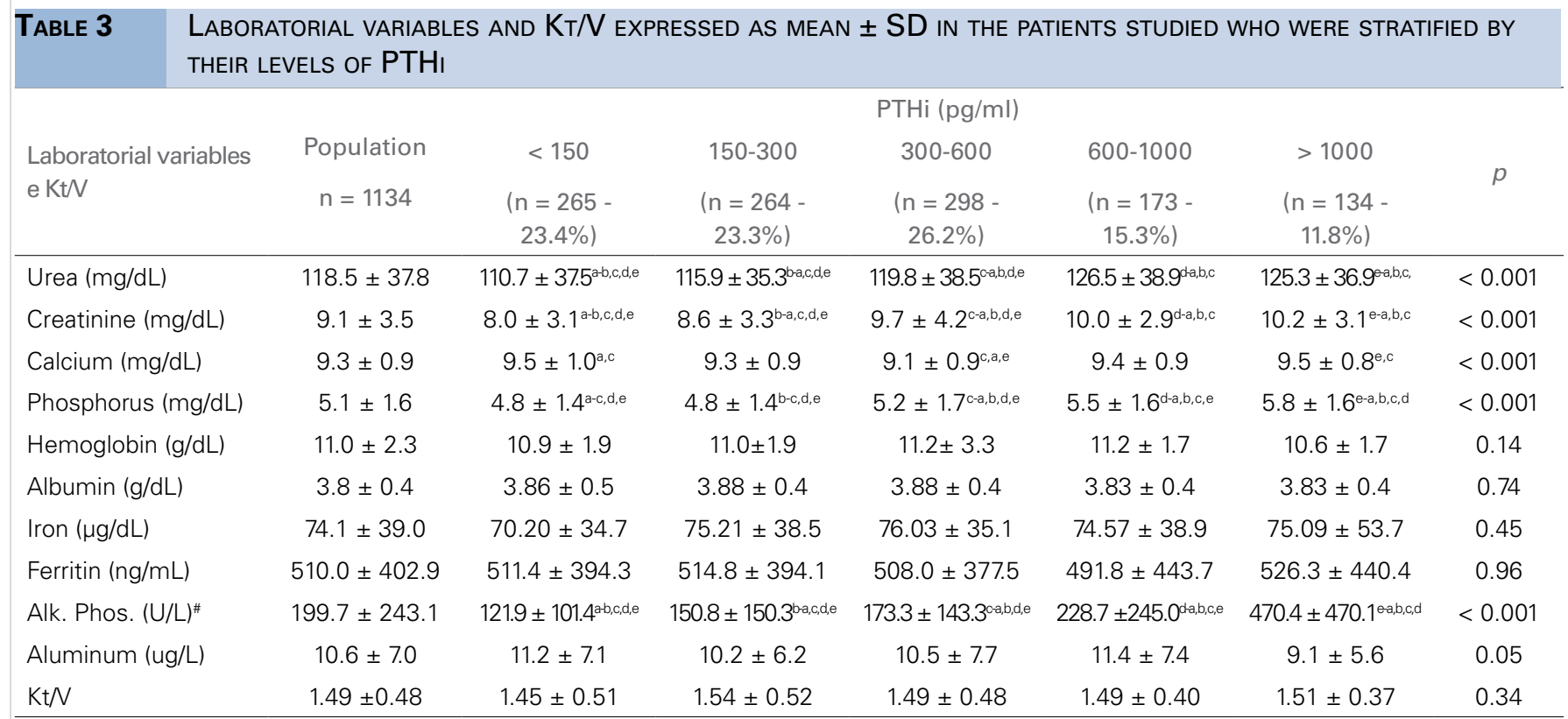

\# Alk. Phos. - Alkaline Phosphatase.

Table 4 Linear Regression using the PTHI LeVel as Dependent VARIABLE

\begin{tabular}{lcccc}
\hline Model 1 & Beta & Sig & \multicolumn{2}{c}{ Confidence interval 95 \% for B } \\
Age & -0.161 & 0.000 & -7.235 & -3.410 \\
Diabetes Mellitus (yes) & -0.104 & 0.001 & -165.884 & -45.411 \\
Time of therapy & 0.188 & 0.000 & 1.130 & 2.170 \\
Dialysis Modality (hemodialysis) & 0.055 & 0.060 & -5.294 & 245.816 \\
\hline
\end{tabular}

start dialytic therapy ${ }^{25}$. This was also observed in this study: a higher prevalence of serum iPTH levels was associated with longer therapy duration.

Regarding drug usage, we found a high percentage of patients using calcium-based phosphate binders $(55.6 \%)$, consistent with the study by Tentori et al., through DOPPS I, II, and III data analysis of 25,558 patients on hemodialysis, which showed a high percentage of these drugs $(72.9 \%)^{26}$. Those authors also found that $17.1 \%$ used sevelamer compared with $14.7 \%$ found in our study. The 2013 Brazilian Chronic Dialysis Survey indicates a higher usage $(38 \%)$ of non-calcium phosphate binders (Sevelamer) ${ }^{4}$, in disagreement with our study, probably due to problems of the public health care system related to drug distribution.

The usage of active vitamin D and analogues (oral and venous calcitriol, alfacalcidol, paricalcitol) in the population studied was $40.2 \%$. However, when analyzing distinct iPTH groups, we observed that $46.7 \%$ of the patients with $\mathrm{iPTH}>1000 \mathrm{pg} / \mathrm{mL}$ used these drugs, while in patients with iPTH $<150 \mathrm{pg} / \mathrm{mL} 30.7 \%$ used them. Because of the cross-sectional nature of this study, some patients might have had a decrease in iPTH associated with the usage of vitamin D or previous (before 2013) parathyroidectomy. Compared to other studies, the use of vitamin D in the present study was low. For instance, in the study by Tentori et al., vitamin D was prescribed to $52 \%$ of the patients, although this was not analyzed as a function of $\mathrm{iPTH}$ level ${ }^{26}$. An Argentinian study revealed that $59.3 \%$ of the patients with $\mathrm{iPTH}>300 \mathrm{pg} / \mathrm{mL}$, and $36.9 \%$ of the patients with iPTH $<150 \mathrm{pg} / \mathrm{mL}$ used active vitamin $\mathrm{D}$ or its analogues ${ }^{15}$.

Taking into consideration the large number of patients with hyperparathyroidism in our study, calcimimetics (Cinacalcet) were underutilized, probably because, even though they are available in Brazil, these drugs are still not freely distributed through the public health care network, unlike calcitriol and other active vitamin $\mathrm{D}$ analogues (e.g., alfacalcidol). Similarly, the low usage of selective vitamin $\mathrm{D}$ receptors activators might be due to same reason.

There was no record of aluminum-based binders in the population studied, and hemodialysis is performed through reverse osmosis in the 11 nephrology centers. Aluminum serum levels were associated with lower iPTH levels in our study. Several authors 
question whether distinct aluminum sources, such as aluminum household utensils, parenteral solutions or foods, could explain this fact ${ }^{27-29}$.

Concerning the dialysate calcium concentrate (DCC), a recent study by Jean and Chazot on hemodialysis shows that different regions of the world have various strategies in relation to this topic. Decreasing the DCC slightly reduces calcemia, but mainly stimulates parathyroid hormone secretion and bone turnover. Conversely, increasing the DCC increases calcemia slightly and reduces parathyroid hormone secretion and bone turnover markedly. Furthermore, higher DCCs favor hemodynamic stability and can prevent ventricular arrhythmias. Even though some studies have shown that using individualized DCCs of 1.25 or $1.75 \mathrm{mmol} / \mathrm{L}$ is not harmful, the real benefits of this strategy need to be assessed in a large, multicenter trial ${ }^{30}$. In peritoneal dialysis, long-term (1-2 year) use of low-calcium dialysate (LCD) with 1.25 $\mathrm{mmol} / \mathrm{L}$ calcium concentration results in decreased serum total and ionized calcium levels and has no effect on phosphate level. No clinical significance in the low calcium change of standard calcium (SCD) bone metabolism was observed between LCD and SCD patients despite low calcium the increase of serum parathyroid hormone in LCD group ${ }^{31}$.

Based on the 2011 Brazilian Census of Parathyroidectomy, $10.7 \%$ of the patients on dialysis presented an iPTH $>1000 \mathrm{pg} / \mathrm{mL}^{9}$, which is in agreement with the results found in our study $(11.8 \%)$. There is no accurate data on the number of parathyroidectomies performed in Brazil. However, a study in Argentina, with a population sample of 1210 patients, showed that 70 patients $(5.8 \%)$ had been submitted to this procedure ${ }^{15}$. As mentioned, no references to parathyroidectomies were found in the records analyzed in our study.

The cross-sectional design of this study is a limitation and therefore some inferences cannot be made. Ionic calcium was not measured and only one $\mathrm{iPTH}$ measurement was performed. The importance of the present study is that, first, it looks at the reality of the dialysis units that serve a large part of the population; and second, it provides a general idea of practice patterns in Brazil, since it does not focus exclusively on data from symptomatic patients or from patients followed up in a CKD-MBD reference center.

We can conclude that the prevalence of patients outside the KDIGO iPTH target was $50.5 \%$.
Hyperphosphatemia occurred in $35.8 \%$ of the studied population and hypophosphatemia in $13.5 \%$. Analysis of the serum calcium showed that $39.3 \%$ of the patients had hypercalcemia while $12.6 \%$ presented with hypocalcemia. There was low usage of active vitamin $\mathrm{D}$, selective vitamin $\mathrm{D}$ receptors activators, and calcimimetic drugs. These data draw attention to the need for stronger compliance with public policies and guidelines regarding the supply of drugs associated with CKD-MBD.

\section{CONFLictS OF INTEREST}

The authors declare no conflict of interest.

\section{AcKNOWLEDgeMENTS}

The authors would like to acknowledge AMGEN Brazil, the Hospital from Universidade Federal de Juiz de Fora, the IMEPEN Foundation, and those responsible at the AMICEN Nephrology Centers as well as their teams: Serviço Ubaense de Nefrologia, Clínica de Tratamento Nefrológico Ltda, Renalclin Clínica de Doenças Renais Ltda, Hemodiálise do Hospital de Cataguases, Centro de Tratamento de Doenças Renais, Hemodiálise da Santa Casa de Misericórdia de Lavras, Clínica Médica Uni-Rim TRS Ltda, Centro Nefrológico Formiguense, Nefroclin Ltda, and Centro Nefrológico de Viçosa.

\section{References}

1. Brasil. Instituto Brasileiro de Geografia e Estatística (IBGE); 2015 [cited 2015 Jun 7]. Available from: http://www.ibge.gov. br/home/

2. Paim J, Travassos C, Almeida C, Bahia L, Macinko J. The Brazilian health system: history, advances, and challenges. Lancet 2011;377:1778-97.

3. International Diabetes Federation. IDF Diabetes Atlas. 6th ed.; 2014 [cited 2015 Jun 8]. Available from: https://www.idf.org/e-library/epidemiology-research/diabetes-atlas/19-atlas-6th-edition.html

4. Sesso RC, Lopes AA, Thome FS, Lugon JR, Dos Santos DR. Brazilian Chronic Dialysis Survey 2013 - trend analysis between 2011 and 2013. J Bras Nefrol 2014;36:476-81.

5. Moe S, Drüeke T, Cunningham J, Goodman W, Martin K, Olgaard $\mathrm{K}$, et al.; Kidney Disease: Improving Global Outcomes (KDIGO). Definition, evaluation, and classification of renal osteodystrophy: a position statement from Kidney Disease: Improving Global Outcomes (KDIGO). Kidney Int 2006;69:194553.

6. Drüeke TB, Massy ZA. Changing bone patterns with progression of chronic kidney disease. Kidney Int 2016;89:289-302.

7. Díaz López JB, Jorgetti V, Caorsi H, Ferreira A, Palma A, Menendez P, et al. Epidemiology of renal osteodystrophy in Iberoamerica. Nephrol Dial Transplant 1998:13:41-5.

8. Araujo SM, Ambrosoni P, Lobão RR, Caorsi H, Moysés RM, Barreto FC, et al. The renal osteodystrophy pattern in Brazil and Uruguay: an overview. Kidney Int Suppl 2003;(85)S54-6. 
9. Oliveira RB, Silva EN, Charpinel DM, Gueiros JE, Neves CL, Sampaio Ede A, et al. Secondary hyperparathyroidism status in Brazil: Brazilian census of parathyroidectomy. J Bras Nefrol 2011;33:457-62.

10. Naves-Díaz M, Passlick-Deetjen J, Guinsburg A, Marelli C, Fernández-Martín JL, Rodríguez-Puyol D, et al. Calcium, phosphorus, PTH and death rates in a large sample of dialysis patients from Latin America. The CORES Study. Nephrol Dial Transplant 2011;26:1938-47.

11. Fernández-Martín JL, Carrero JJ, Benedik M, Bos WJ, Covic A, Ferreira A, et al. COSMOS: the dialysis scenario of CKD-MBD in Europe. Nephrol Dial Transplant 2013;28:1922-35.

12. Fernandes N, Bastos MG, Cassi HV, Machado NL, Ribeiro JA, Martins G, et al.; Brazilian Peritoneal Dialysis Multicenter Study. The Brazilian Peritoneal Dialysis Multicenter Study (BRAZPD): characterization of the cohort. Kidney Int Suppl 2008; (108)S145-51.

13. Bover J, Ureña P, Brandenburg V, Goldsmith D, Ruiz C, DaSilva I, et al. Adynamic bone disease: from bone to vessels in chronic kidney disease. Semin Nephrol 2014;34:626-40.

14. Secretaria de Estado de Saúde de Minas Gerais. Adscrição e população por municípios por macrorregião e microrregião de saúde - Estimativa IBGE/TCU 2014 [cited 2015 Jun 8]. Available from: http://www.saude.mg.gov.br/images/ anexos/PDR/Adscricao_e_populacao_dos_municipios_por_ macrorregioes_e_microrregioes_de_saude.pdf

15. Douthat WG, Castellano M, Berenguer L, Guzmán MA, de Arteaga J, Chiurchiu CR, et al. High prevalence of secondary hyperparathyroidism in chronic kidney disease patients on dialysis in Argentina. Nefrologia 2013;33:657-66.

16. Kiss I, Kiss Z, Ambrus C, Szabó A, Szegedi J, Balla J, et al.; CKD-MBD Working Group of Hungarian Society of Nephrology. Age-dependent parathormone levels and different CKD-MBD treatment practices of dialysis patients in Hungary--results from a nationwide clinical audit. BMC Nephrol 2013:14:155.

17. Brandenburg VM, Floege J. Adynamic bone disease-bone and beyond. NDT Plus 2008;1:135-47.

18. Nobles M. History counts: a comparative analysis of racial/ color categorization in US and Brazilian censuses. Am J Public Health Res 2000;90:1738-45.

19. Dos Reis LM, Batalha JR, Muñoz DR, Borelli A, Correa PH, Carvalho $\mathrm{AB}$, et al. Brazilian normal static bone histomorphometry: effects of age, sex, and race. J Bone Miner Metab 2007;25:400-6.
20. Jovanovich A, Chonchol M, Cheung AK, Kaufman JS, Greene T, Roberts WL, et al.; HOST Investigators. Racial differences in markers of mineral metabolism in advanced chronic kidney disease. Clin J Am Soc Nephrol 2012;7:640-7.

21. Kalantar-Zadeh K, Miller JE, Kovesdy CP, Mehrota R, Lukowsky LR, Streja E, et al. Impact of race on hyperparathyroidism, mineral disarrays, administered vitamin D mimetic, and survival in hemodialysis patients. J Bone Miner Res 2010;25:2724-34.

22. Andress DL, Hercz G, Kopp JB, Endres DB, Norris KC, Coburn JW, et al. Bone histomorphometry of renal osteodystrophy in diabetic patients. J Bone Min Res 1987;2:525-31.

23. Diaz Corte C, Rodríguez A, Naves ML, Fernández Martín JL, Cannata JB. [Bone metabolic markers and use of vitamin D in dialysis. Multicenter survey. (II). Collaborative Centers of the Multicenter Study on Renal Osteodystrophy]. Nefrologia 2000;20:244-253. Spanish.

24. Sherrard DJ, Hercz G, Pei Y, Maloney NA, Greenwood C, Manuel $\mathrm{A}$, et al. The spectrum of bone disease in end-stage renal failure--an evolving disorder. Kidney Int 1993;43:436-42.

25. Gueiros JE, Hernandes FR, Karohl C, Jorgetti V; Sociedade Brasileira de Nefrologia. [Prevention and treatment of secondary hyperparathyroidism in CKD]. J Bras Nefrol 2011;33:7-14. Portuguese.

26. Tentori F, Blayney MJ, Albert JM, Gillespie BW, Kerr PG, Bommer J, et al. Mortality risk for dialysis patients with different levels of serum calcium, phosphorus, and PTH: the Dialysis Outcomes and Practice Patterns Study (DOPPS). Am J Kidney Dis 2008;52:519-30.

27. Gura KM. Aluminum contamination in parenteral products. Curr Opin Clin Nutr Metab Care 2014;17:551-7.

28. Lin JL, Yang YJ, Yang SS, Leu ML. Aluminum utensils contribute to aluminum accumulation in patients with renal disease. Am J Kidney Dis 1997;30:653-8.

29. Willhite CC, Karyakina NA, Yokel RA, Yenugadhati N, Wisniewski TM, Arnold IM, et al. Systematic review of potential health risks posed by pharmaceutical, occupational and consumer exposures to metallic and nanoscale aluminum, aluminum oxides, aluminum hydroxide and its soluble salts. Crit Rev Toxicol 2014;44:1-80.

30. Jean G, Chazot C. Individualizing the dialysate calcium concentration. Curr Opin Nephrol Hypertens 2015;24:538-45.

31. Cao XY, Zhou JH, Cai GY, Ding R, Tang L, Wu D, et al. Long term effects on mineral and bone metabolism by low versus standard calcium dialysate in peritoneal dialysis: a meta-analysis. Int J Clin Exp Med 2015;8:2031-7. 